\title{
PRODUKTIVITAS TANAMAN KALIANDRA (Calliandra calothyrsus) SEBAGAI HIJAUAN PAKAN PADA UMUR PEMOTONGAN YANG BERBEDA
}

\section{PRODUCTIVITY OF CALLIANDRA (Calliandra calothyrsus) AS A FORAGE IN THE DIFFERENT DEFOLIATION TIME}

\author{
Abqoriyah, Ristianto Utomo, dan Bambang Suwignyo* \\ Fakultas Peternakan, Universitas Gadjah Mada, Yogyakarta, 55281
}

Submitted: 12 May 2014, Accepted: 2 March 2015

\section{INTISARI}

Penelitian ini bertujuan untuk mengetahui kandungan nutrien dan produksi tanaman kaliandra sebagai hijauan pakan pada umur pemotongan yang berbeda. Penelitian dilaksanakan selama 48 minggu (Juni 2012 sampai Juni 2013) di Lahan Hijauan Pakan Ternak, Satuan Kerja Kaligesing, Purworejo, Dinas Peternakan Jawa Tengah. Penelitian menggunakan metode Rancangan Acak Kelompok. Blocking dilakukan terhadap kemiringan tanah. Pemanenan berdasarkan perlakuan umur pemotongan yaitu: 6 (P1), 8 (P2), 12 (P3), dan 16 (P4) minggu. Tanaman kaliandra sebelum digunakan dilakukan penyeragaman umur pemotongan tanaman.Tanaman kaliandra pada saat pemanenan dipotong berdasarkan edible portion (bagian yang dapat dimakan oleh ternak yaitu batang muda dan daun). Variabel yang diamati adalah produksi bahan segar, bahan kering, bahan organik, dan protein kasar, serta kadar bahan kering, bahan organik, protein kasar, lemak kasar, serat kasar, bahan ekstrak tanpa nitrogen (BETN), dan total digestible nutrient (TDN). Hasil analisis menunjukkan bahwa kadar bahan kering tertinggi terdapat pada P3 $(31,25 \%)$ dan berbeda nyata $(\mathrm{P}<0,05)$ dengan $\mathrm{P} 1(26,51 \%)$ dan $\mathrm{P} 4(28,11 \%)$. Kadar protein kasar tertinggi pada perlakuan P2 $(21,10 \%)$ dan tidak berbeda nyata dengan P1 $(21,09 \%)$, P3 $(19,20 \%)$, kadar protein kasar terendah terdapat pada perlakuan P4 (18,04\%). Kadar lemak tertinggi terdapat pada P3 $(2,84 \%)$ dan berbeda nyata dengan $\mathrm{P} 1(1,51 \%)$. Kadar serat kasar tertinggi terdapat pada P4 $(22,56 \%)$ dan berbeda nyata dengan P1 (15,80\%) dan P2 (18,46\%). Kadar bahan organik, BETN, dan TDN berbeda tidak nyata pada umur pemotongan yang berbeda. Produksi bahan segar, bahan kering, bahan organik, dan protein kasar tertinggi terdapat pada P4 dan berbeda nyata $(\mathrm{P}<0,05)$ dengan $\mathrm{P} 1, \mathrm{P} 2$, dan $\mathrm{P} 3$. Produksi terendah terdapat pada perlakuan P2. Kualitas hijauan terbaik pada penelitian ini diperoleh dari perlakuan ketiga (dengan frekuensi pemotongan 4 kali), sedangkan kuantitas hijauan terbaik diperoleh dari perlakuan keempat (dengan frekuensi pemotongan 3 kali).

(Kata kunci: Kaliandra, Kandungan nutrien, Produksi, Umur pemotongan)

\section{ABSTRACT}

This research aimed to determine the production and nutrient content of calliandra (Caliandra calothyrsus) as a forage for ruminant in the different defoliation time. This research was conducted for 48 weeks (June 2012-June 2013) at Kaligesing forage feed area, Animal Science Department, Purworejo, Central Java. Design of the research was Completely Randomized Block Design. Soil slope was used as block. The research treatments were $6(P 1), 8(P 2), 12(P 3)$ and $16(P 4)$ weeks of cutting age. The grass of all treatment groups were cut together at the same day prior to experiment. Caliandra calothyrsus was cut at edible portion. Parameters measured were fresh forage, dry matter, organic matter and crude protein production and also nutrient content namely dry matter, organic matter, crude protein, extract ether, crude fiber, BETN and TDN. The result showed that the highest dry matter content was found in $P 3(31.25 \%)$ and was different from $P 1$ (26.51\%) and P4 (28.12\%). The highest crude protein content was found in $P 2$ (21.10\%) and was not different with $P 1(21.09 \%)$ and $P 3(19.20 \%)$, and the lowest crude protein was found inP4 (18.04\%). The highest extract ether was at P3 (2.84\%) and different from P1 (1.51\%). The highest crude fiber was at $P 4$ (22.56\%) different with $P 1$ (15.80\%) and $P 2$ (18.46\%). Organic matter, BETN and TDN were not different among the different defoliation time. The highest fresh forage, dry matter, organic matter and crude protein production were at $P 4$ and different $(P<0.05)$ from $P 1, P 2$ and $P 3$. The lowest dry matter was at $P 2$. It is concluded that the best quality of grass was found in $P 3$ group and the highest harvesting quantity was found in P4 group.

(Key words: Calliandra calothyrsus, Cutting age, Nutrient content, Production)

\footnotetext{
${ }^{*}$ Korespondensi (corresponding author):

Telp.+62 85878728488, E-mail: bsuwignyo@ugm.ac.id
} 


\section{Pendahuluan}

Peningkatan produksi ternak ruminansia berhubungan erat dengan penyediaan dan penggunaan hijauan pakan. Produktivitas hijauan pakan mencakup nilai kualitas dan kuantitas hijauan pakan tersebut. Kualitas hijauan pakan meliputi nilai nutrien dan tingkat konsumsi hijauan tersebut oleh ternak, sedangkan kuantitas hijauan pakan adalah nilai yang diperoleh dari pengukuran secara mekanis terhadap hijauan pakan yaitu dengan cara pemotongan dan penimbangan.

Sumber hijauan yang tersedia sepanjang tahun dengan kualitas dan kuantitas yang tinggi perlu diupayakan. Leguminosa merupakan hijauan pakan yang dapat meningkatkan kualitas nutrisi dan dapat mensuplai protein. Kaliandra merupakan tanaman yang tergolong dalam kelompok leguminosa dan banyak dimanfaatkan peternak sebagai pakan. Kaliandra cukup potensial sebagai pakan sumber protein yaitu mengandung 20-25\% (Willyan et al., 2007), mengandung anti nutrisi (tanin) sampai $11 \%$ (Tangendjaja dan Wina, 2000).

Tanaman kaliandra berasal dari Meksiko, Amerika Tengah, masuk ke Indonesia pada tahun 1936 lewat pulau Jawa (Stewart et al., 2001). Tanaman kaliandra masuk ke pulau Jawa berasal dari Guatemala selatan yaitu spesies Caliandra calothyrsus berbunga merah dan Caliandra tetragona berbunga putih, Caliandra calothyrsus memiliki ketinggian tanaman berkisar antara 4-6 $\mathrm{m}$, akan tetapi apabila lingkungan memungkinkan dapat tumbuh sampai $12 \mathrm{~m}$ dengan diameter batang mencapai $30 \mathrm{~cm}$. Daun kaliandra berwarna hijau gelap, kanopi melebar ke samping, dan sangat padat. Tipe daun kaliandra merupakan daun majemuk yang berpasangan (Tangendjaja et al., 1992).

Paterson et al. (1999) melaporkan bahwa umur pemanenan pertama untuk hijauan pakan ternak kaliandra sebaiknya pada umur 9-12 bulan, dan seterusnya dapat dipanen setiap 4-6 kali setahun tergantung kondisi tanahnya. Kandungan nutrien tanaman menurun dengan makin tua umur tanaman. Kadar protein akan menurun dengan makin tuanya umur tanaman, sedangkan kadar serat kasar akan meningkat dengan makin tua umur tanaman (Tillman et al., 1998).

Penelitian bertujuan untuk mengetahui kandungan nutrien dan produksi tanaman kaliandra pada umur pemotongan yang berbeda sehingga dapat menggambarkan produktivitas hijauan kaliandra sebagai pakan ternak.

\section{Materi dan Metode}

Penelitian ini dilaksanakan di Lahan Hijauan Pakan Ternak Satuan Kerja Kaligesing, Dinas Peternakan Jawa Tengah, Kecamatan Kaligesing, Purworejo. Analisis laboratorium dilaksanakan di Laboratorium Teknologi Makanan Ternak Fakultas Peternakan, Universitas Gadjah Mada, Yogyakarta. Penelitian dilaksanakan selama 48 minggu (Juni 2012 sampai Juni 2013).

Bahan yang digunakan dalam penelitian ini adalah tanaman kaliandra yang sudah ditanam sejak tahun 2008 di Lahan Hijauan Pakan Ternak Satuan Kerja Kaligesing, Dinas Peternakan Jawa Tengah, Purworejo yang ditanam dengan jarak satu meter. Tanaman kaliandra sebelum diberi perlakuan dilakukan penentuan jumlah tanaman dan penyeragaman umur pemotongan tanaman secara bersama pada hari yang sama. Tanaman dibiarkan tumbuh tanpa dilakukan pemupukan dan penyiraman selama penelitian.

Setiap tanaman dilakukan pemeliharaan selama 48 minggu, dan dilakukan pemanenan berdasarkan perlakuan umur pemotongan yaitu: $\mathrm{P} 1=$ umur 6 minggu dengan frekuensi 8 kali pemotongan, $\mathrm{P} 2=$ umur 8 minggu dengan frekuensi 6 kali pemotongan, $\mathrm{P} 3=$ umur 12 minggu dengan frekuensi 4 kali pemotongan, $\mathrm{P} 4=$ umur 16 minggu dengan frekuensi 3 kali pemotongan.

Tiap tanaman akan dilakukan pemotongan berdasarkan perlakuan yang ditentukan dan sampel pemanenan akan diambil $40 \%$ dari total pemanenan. Tanaman kaliandra pada saat pemanenan dipotong berdasarkan edible portion (bagian yang dapat dimakan oleh ternak, terdiri dari semua batang muda dan daun). Sampel yang telah didapat ditimbang kembali dan dimasukkan dalam kantong koran yang telah diketahui beratnya, kemudian dikeringkan dalam oven pada suhu $55^{\circ} \mathrm{C}$. Setelah itu dilakukan penimbangan kembali. Sampel yang sudah kering tersebut selanjutnya digiling dengan menggunakan wiley mill dengan diameter lubang 1 milimeter dan disimpan di dalam freezer untuk selanjutnya dilakukan analisis. Sampel yang telah digiling kemudian dianalisis kadar bahan kering, bahan organik, protein kasar, ekstrak eter, dan serat kasar, 
bahan ekstrak tanpa nitrogen (BETN) berdasarkan petunjuk AOAC (2005), nilai total digestible nutrient (TDN) dihitung dengan rumus yang dikemukakan oleh Hartadi et al. (2005) yaitu persamaan perhitungan \%TDN bahan pakan kelas 2 karena kaliandra termasuk hijauan yang dipotong maupun tidak dipotong yang diberikan segar pada ternak.

Data yang dihasilkan dari percobaan dianalisis dengan Rancangan Acak Kelompok. Blocking dilakukan terhadap kemiringan tanah. Apabila uji F menunjukkan adanya pengaruh nyata dari masing-masing perlakuan, dilanjutkan dengan uji Duncan's Multiple Ranges Test pada tingkat ketelitian 5\% (Astuti, 2007).

\section{Hasil dan Pembahasan}

\section{Komposisi kimia}

Rerata komposisi kimia tanaman kaliandra yang dipotong pada umur pemotongan yang berbeda, disajikan pada Tabel 1. Hasil analisis variansi menunjukkan bahwa keempat perlakuan memberikan pengaruh yang nyata $(P<0,05)$ terhadap kadar bahan kering, protein kasar, lemak kasar, dan serat kasar tanaman kaliandra. Rerata kadar bahan kering tanaman kaliandra meningkat seiring dengan semakin tua umur pemotongan, kecuali pada pemotongan perlakuan ke-4 mengalami penurunan. Hal ini diduga karena adanya perubahan musim. Pemanenan perlakuan ke-4 yang terjadi pada musim hujan (Oktober), sedangkan pemanenan perlakuan lainnya terjadi pada musim kemarau (Agustus sampai September). Murphy (2002) menyatakan bahwa cahaya adalah faktor lingkungan yang diperlukan untuk mengendalikan pertumbuhan dan perkembangan tumbuhan, alasan utamanya tentu saja karena cahaya menyebabkan fotosintesis.

Semakin tua umur pemotongan (sampai 12 minggu) kadar bahan keringnya meningkat. Hal tersebut diduga karena pada umur pemotongan yang lebih pendek (umur muda) kadar air tanaman lebih banyak dibandingkan dengan umur tua. Semakin tua umur tanaman kadar serat kasarnya akan semakin meningkat sehingga kadar air semakin berkurang. Hal tersebut sesuai dengan pendapat Salisbury et al. (1995) yang menyatakan bahwa umur tanaman dapat mempengaruhi kadar air dalam bahan tanaman, kadar bahan kering semakin meningkat seiring dengan semakin tua umur tanaman tersebut. Berdasarkan hasil analisis terhadap bahan organik berbeda tidak nyata $(P>0,05)$ pada keempat perlakuan.

Rerata kadar protein kasar hijauan kaliandra mengalami penurunan dengan umur pemotongan yang lebih lama, sedangkan kadar lemak kasar dan serat kasar mengalami kenaikan. Dalam penelitian ini hasil analisis variansi menunjukkan bahwa keempat perlakuan memberikan pengaruh yang nyata $(P<0,05)$ terhadap kadar protein kasar, lemak kasar dan serat kasar dari tanaman kaliandra. Davies (1982) menyatakan bahwa kadar protein kasar menurun dengan umur tanaman yang semakin meningkat, karena komponen dinding sel bertambah sedangkan isi sel mengalami penurunan. Protein adalah bagian utama dari jaringan-jaringan yang aktif, dengan demikian daun mengandung lebih banyak nutrisi tersebut daripada tangkainya, apabila tanaman menjadi tua terjadi suatu perpindahan protein dari bagian vegetatif ke bijinya untuk keperluan pertumbuhan biji.

Hasil analisis variansi menunjukkan bahwa umur pemotongan tanaman kaliandra berpengaruh nyata $(P<0,05)$ terhadap kadar lemak. Kadar lemak terendah pada P1 (pemotongan umur 6 minggu) dan semakin meningkat dengan peningkatan umur pemotongan. Hasil ini sesuai dengan penelitian Koten (2013) bahwa pada tanaman legum (arbila) semakian tinggi kadar lemak dengan umur pemotongan yang semakin lama. Lemak merupakan bagian dari protoplas. Meningkatnya fase pertumbuhan tanaman dari vegetatif ke generatif, menyebabkan protoplas pada bagian vegetatif tanaman akan berkurang, sehingga berdampak pada kadar lemak.

Tinggi rendahnya kadar serat kasar suatu hijauan pakan merupakan salah satu indikator tentang kualitas hijauan. Rerata kadar serat kasar meningkat dengan semakin lama umur pemotongan. Hasil analisis variansi menunjukkan bahwa umur pemotongan berpengaruh nyata $(P<0,05)$ terhadap kadar serat kasar kasar. Gardner et al. (1991) menyatakan bahwa umur pemanenan yang lebih lama memiliki kesempatan lebih banyak bagi sel tanaman untuk menyusun serabut dinding selnya sehingga kadar serat kasar yang merupakan struktur utama dinding sel menjadi semakin banyak jumlahnya. Kadar serat kasar yang 
tinggi pada tanaman tua karena kadar serat kasar berkaitan dengan umur tanaman. Semakin tua umur tanaman semakin meningkat kadar serat kasar. Adanya variasi perbedaan tersebut diduga oleh perbedaan jumlah akumulasi hasil fotosintesis (Purbajanti, 2013) dan variasi kadar protein masing-masing perlakuan (Davies, 1982).

Kadar BETN diperoleh dari pengurangan kadar air, abu, protein, lemak, dan serat kasar sehingga nilainya dipengaruhi oleh kandungan nutrien lain tersebut. Hasil analisis variansi menunjukkan bahwa umur pemotongan tidak mempengaruhi kadar BETN pada keempat perlakuan. Diduga bahwa turunnya kadar protein kasar pada suatu perlakuan diimbangi dengan naiknya kadar serat kasar pada perlakuan lain sehingga mempengaruhi total hasil pengurangan.

Rerata nilai TDN tanaman kaliandra semakin meningkat dengan umur pemotongan yang lebih lama, namun berdasarkan hasil analisis variansi menunjukkan pengaruh yang berbeda tidak nyata. Hartadi et al. (2005) menyatakan bahwa nilai TDN dipengaruhi oleh kadar serat kasar, protein kasar, lemak kasar, dan BETN. Hasil komposisi kimia yang tinggi tersebut akan meningkatkan nilai TDN dari bahan pakan, sebaliknya apabila komposisi kimia bahan tersebut rendah maka akan menurunkan nilai TDN.

Tillman et al. (1998) menyebutkan bahwa lemak kasar pada tanaman terdiri dari sterol, lilin (wax), berbagai produk seperti vitamin $A$ dan vitamin D, serta klorofil. Menurut Ai dan Banyo (2011), klorofil merupakan pigmen utama pada tanaman. Klorofil memiliki fungsi utama dalam fotosintesis yaitu memanfaatkan energi matahari, memicu fiksasi $\mathrm{CO}_{2}$ untuk menghasilkan karbohidrat dan menyediakan energi. Diduga semakin lama umur pemotongan tanaman akan mendapatkan cahaya yang cukup sehingga klorofil semakin tinggi yang dapat meningkatkan kadar lemak kasar. Kadar lemak kasar dalam penelitian ini semakin tinggi dengan umur pemotongan yang lebih lama, tingginya kadar lemak menyebabkan terjadinya peningkatan nilai TDN dengan umur pemotongan yang lebih lama.

Produksi bahan segar, bahan kering,
bahan organik, dan protein kasar Produksi hijauan kaliandra yang dipotong pada umur yang berbeda tersaji pada Tabel 2. Rerata produksi bahan segar antar perlakuan semakin meningkat dengan umur pemotongan yang lebih lama. Hal ini disebabkan karena makin banyaknya waktu yang tersedia bagi tanaman untuk berfotosintesis di dalam jaringan tanaman (Koten, 2013). Produksi terendah terdapat pada P1 (0,53 ton/ha/th) dan P2 (0,51 ton/ha/th) dengan frekuensi pemotongan sebanyak 8 dan 6 kali dalam setahun, Sedangkan produksi tertinggi pada P4 (3,05 ton/ha/th) meskipun dengan frekuensi pemotongan sebanyak 3 kali dalam setahun. Dalam penelitian ini hasil analisis variansi menunjukkan bahwa keempat perlakuan memberikan pengaruh yang nyata $(P<0,05)$ terhadap produksi bahan segar tanaman kaliandra. Boschini (2002) menyatakan bahwa umur tanaman berpengaruh pada kandungan nutrisi dan produksi tanaman. Pemotongan lebih awal akan meningkatkan kandungan protein kasar pada daun dan batang, namun menurun pada produksi biomassa dan menurun pada kandungan dinding sel. Pada pemotongan yang lebih

Tabel 1. Komposisi kimia tanaman kaliandra pada umur yang berbeda (chemical composition of caliandra calothyrsus in the different defoliation)

\begin{tabular}{|c|c|c|c|c|}
\hline \multirow{2}{*}{ Komposisi kimia (\%BK) (chemical composition (\% DM)) } & \multicolumn{4}{|c|}{ Perlakuan (treatment) } \\
\hline & $\mathrm{P} 1$ & P2 & P3 & P4 \\
\hline Bahan kering (dry mattter) & $26,51^{\mathrm{c}}$ & $29,55^{b}$ & $31,25^{a}$ & $28,11^{b c}$ \\
\hline Bahan organik (organic matter) $)^{\text {ns }}$ & 93,43 & 93,17 & 92,49 & 92,76 \\
\hline Protein kasar (crude protein) & $21,09^{a}$ & $21,10^{a}$ & $19,20^{\mathrm{ab}}$ & $18,04^{\mathrm{b}}$ \\
\hline her extract) & $1,51^{b}$ & $1,86^{\mathrm{ab}}$ & $2,84^{a}$ & $2,83^{a}$ \\
\hline de fiber) & $15,80^{c}$ & $18,46^{\mathrm{bc}}$ & $20,27^{\mathrm{ab}}$ & $22,56^{a}$ \\
\hline no nitrogon (nitrogen frop prtrastins & 50,28 & 50,28 & 52,22 & 53,54 \\
\hline Total digestible nutrients (TDN) ${ }^{\text {ns }}$ & 65,46 & 70,23 & 80,35 & 82,22 \\
\hline \multicolumn{5}{|c|}{$\begin{array}{l}\text { P1: dipotong umur } 6 \text { minggu (cutting of age } 6 \text { weeks), P2: dipotong umur } 8 \text { minggu (cutting of age } 8 \text { weeks), P3: dipotong } \\
\text { umur } 12 \text { minggu (cutting of age } 12 \text { weeks), P4: dipotong umur } 16 \text { minggu (cutting of age } 16 \text { weeks). } \\
\text { a,b,c Superskrip yang berbeda pada baris yang sama menunjukkan perbedaan yang nyata }(P<0,05)(\text { different superscript } \\
\text { at the same row indicate significant differences }(P<0.05) \text { ). } \\
\text { ns berbeda tidak nyata (non significant). }\end{array}$} \\
\hline
\end{tabular}


Tabel 2. Rerata produksi bahan segar, bahan kering, bahan organik, dan protein kasar tanaman kaliandra pada umur yang berbeda

(average of fresh matter, dry matter, organic matter and crude fiber production of caliandra calothyrsus at different defoliation)

\begin{tabular}{lcccc}
\hline \hline $\begin{array}{c}\text { Produksi (ton/ha/th) } \\
\text { (production (ton/ha/year)) }\end{array}$ & $\mathrm{P} 1$ & \multicolumn{3}{c}{ Perlakuan (treatment) } \\
\cline { 2 - 5 } Bahan segar (fresh matter) & $0,53^{\mathrm{c}}$ & $0,51^{\mathrm{c}}$ & $\mathrm{P} 3$ & $\mathrm{P} 4$ \\
\hline Bahan kering (dry matter) & $0,13^{\mathrm{c}}$ & $0,13^{\mathrm{b}}$ & $0,32^{\mathrm{b}}$ & $0,87^{\mathrm{a}}$ \\
Bahan organik (organic matter) & $0,12^{\mathrm{c}}$ & $0,12^{\mathrm{c}}$ & $0,29^{\mathrm{b}}$ & $0,80^{\mathrm{a}}$ \\
Protein kasar (crude protein) & $0,03^{\mathrm{c}}$ & $0,03^{\mathrm{c}}$ & $0,06^{\mathrm{b}}$ & $0,16^{\mathrm{a}}$ \\
\hline P1: dipotong umur 6 minggu (cutting of age 6 weeks), P2: dipotong umur 8 minggu (cutting of age 8 weeks), P3: dipotong \\
umur 12 minggu (cutting of age 12 weeks), P4: dipotong umur 16 minggu (cutting of age 16 weeks). \\
a,b,c Superskrip yang berbeda pada baris yang sama menunjukkan perbedaan yang nyata (P<0,05) (different superscript \\
at the same row indicate significant differences (P<0.05)).
\end{tabular}

sering akan mengakibatkan pertumbuhan kembali hijauan pakan terhambat dan menurunkan produksi hijauan segarnya.

Hasil analisis variansi produksi bahan kering menunjukkan perbedaan yang nyata $(P<0,05)$ pada umur pemotongan yang berbeda. Peningkatan produksi bahan segar akan meningkatkan produksi bahan keringnya karena produksi bahan kering merupakan hasil kali produksi bahan segar dengan kadar bahan kering (Wong et al., 2008). Sitompul dan Guritno (1995) juga menyatakan bahwa peningkatan produksi hijauan segar akan diikuti dengan peningkatan bahan keringnya. Pada tanaman yang tua hasil aktivitas fotosintesis selain digunakan untuk pertumbuhan juga disimpan sebagai cadangan makanan sehingga kandungan dan produksi bahan kering bertambah dengan meningkatnya umur pemotongan.

Data pada Tabel 2 menunjukkan bahwa perbedaan umur pemotongan berbeda nyata $(P<0,05)$ terhadap produksi bahan organik. Peningkatan produksi bahan organik pada P3 meningkat 2 kali lipat dan P4 meningkat hampir 5 kali lipat dari perlakuan P1 maupun P2. Produksi bahan organik yang tinggi pada P4 ini juga didukung dengan produksi bahan segar, bahan kering, dan protein kasar.

Hasil analisis dalam penelitian menunjukkan bahwa produksi protein kasar tertinggi terdapat pada P4 (0,16 ton/ha/th) dan berbeda nyata $(P<0,05)$ dengan $P 1, P 2$, dan P3. Data menunjukkan bahwa produksi protein kasar tertinggi terdapat pada $\mathrm{P} 4(0,16)$ dan memberikan pengaruh yang nyata $(\mathrm{P}<0,05)$ pada $\mathrm{P} 1, \mathrm{P} 2$, dan $\mathrm{P} 3$. Balabanli et al. (2010) menyatakan bahwa produksi protein kasar hijauan pakan tergantung pada produksi bahan kering dan kadar protein kasar hijauan.

\section{Kesimpulan}

Semakin tua umur pemotongan tanaman kaliandra semakin tinggi kandungan bahan kering, bahan organik, serat kasar, lemak kasar, dan produksi hijauan, tetapi kadar protein semakin menurun. Kualitas hijauan yang terbaik dari penelitian ini diperoleh dari perlakuan ketiga yaitu tanaman kaliandra yang dipotong umur 12 minggu dengan frekuensi pemotongan sebanyak 4 kali, dilihat dari kadar bahan kering dan protein kasar. Kuantitas hijauan yang terbaik dari penelitian ini diperoleh dari perlakuan keempat yaitu tanaman kaliandra yang dipotong umur 16 minggu dengan frekuensi pemotongan sebanyak 3 kali, dilihat dari produksi hijauan bahan segar, bahan kering, dan protein kasar yang semakin tinggi.

\section{Daftar Pustaka}

Ai, N. S. dan Y. Banyo. 2011. Konsentrasi klorofil daun sebagai indikator kekurangan air pada tanaman. Jurnal IImiah Sains 11: 166-171.

AOAC. 2005. Official Method of Analysis of the Association of Official Analitycal Chemist. $18^{\text {th }}$ edn. Published by the Association of Official Analytical Chemists, Washington.

Astuti, M. 2007. Pengantar IImu Statistik Untuk Peternakan dan Kesehatan Hewan. Binasti Publisher, Bogor.

Balabanli, C., S. Albayrak and O. Yuksel. 2010. Effect of nitrogen, phosporus and pottassium fertilization on the quality and yield of native rangeland. Turkish $\mathrm{J}$. Field Crops 15: 126-130. 
Boschini, C. F. 2002. Nutritional quality of mulberry cultivation for ruminant feeding. In: Mulberry for Animal Production Proceedings of an Electronic Conference. Carried out on May and August 2000. Sanchaz, M. D. (ed) Roma: FAO Animal Production and Health Paper. pp. 173 -182.

Davies, H. L. 1982. Nutrition and Growth Manual. Australian-Asian Universities Cooperation Scheme, Canbera.

Gardner, F. P., R. B. Pearce, dan R. J. Mitchell. 1991. Fisiologi Tanaman Budidaya. Terjemahan. UI Press, Jakarta.

Hartadi, H., S. Resohadiprodjo, dan A. D. Tillman. 2005. Tabel Komposisi Pakan untuk Indonesia. Gadjah Mada Press, Cetakan kelima, Yogyakarta.

Koten, B. B. 2013. Tumpangsari legum arbila (Phaseolus lunatus L.) berinokulum rizobium dengan sorgum (Sorghum bicolor (L) Moench) dalam upaya meningkatkan produktivitas hijauan pakan ruminansia. Disertasi Program Pascasarjana UGM, Yogyakarta.

Murphy, B. 2002. Greener Pastures on Your Side of the Fence. $4^{\text {th }}$ edn. Arriba Publishing, Vermont. 39-100.

Paterson, R. T., E. Kiruiro and H. K. Arimi. 1999. Caliandra calothyrsus as a supplement for milk production in the Kenya Highlands. Tropic. Anim. Health Prod. 31: 115-126.

Purbajanti, E. D. 2013. Rumput dan Legum Sebagai Hijauan Makanan Ternak. Graha Ilmu, Semarang.

Salisbury, F., B. Ross, dan W. Cleon. 1995. Fisiologi Tumbuhan Jilid Dua: Biokimia Tumbuhan. ITB Press, Bandung.
Sitompul, S. M. and B. Guritno. 1995. Analisis Pertumbuhan Tanaman. Gadjah Mada Press, Yogyakarta.

Stewart, J., Mulawarman, J. M. Roshetko, dan M. H. Powell. 2001. Produksi dan Pemanfaatan Kaliandra (Caliandra calothyrsus). Winrock International and International Centre for Research in Agroforestry.

Tangendjaja, B., E. Wina, T. Ibrahim, dan B. Palmer. 1992. Kaliandra (Caliandra calothyrsus) dan Pemanfaatannya. Balai Penelitian Ternak dan The Australian Center for International Agricultural Research.

Tangendjaja, B. and E. Wina. 2000. Tannins and ruminant production in Indonesia. In: Brooker, Tannins in Livestock and Human Nutrition. ACIAR Proceeding 92: 40-43.

Tillman, A. D, H. Hartadi, S. Reksohadiprodjo, S. Prawirokusumo, dan S. Lebdosoekojo. 1998. IImu Makanan Ternak Dasar. Gadjah Mada Press, Yogyakarta.

Willyan, D., S. Kuswaryan, dan U. H. Tanuwiria. 2007. Efek substitusi konsentrat dengan daun kering kaliandra dalam ransum sapi perah terhadap kuantitas dan kualitas susu, bobot badan dan pendapatan peternak. Seminar Nasional Teknologi Peternakan dan Veteriner, Fakultas Peternakan, Universitas Padjadjaran, Bandung.

Wong, C. C., M. D. M. Daham and O. Abdullah. 2008. Effects of defoliation (cutting) on forage yield and quality of selected kenaf accessions. J. Trop. Agric. Feed. Sci. 36: 21-28. 